\title{
The European Union between
} Intergovernmentalism and 'Shared and Responsible Sovereignty': The Haptic Potential of EMU's Institutional Architecture (The Government and Opposition/Leonard Schapiro Lecture, 2016)

\begin{abstract}
The article starts from a critique of the widespread assumption that intergovernmentalism is not only the more practical but also the more democratic way of handling the current European crises - and particularly the euro crisis - to argue for the need to rethink the working and the definition of democracy in the current heightened interconnectedness of political organization. It suggests that perceiving European citizens as being separated into distinct state communities stands in the way of a full appreciation of the externalities, hence of the reciprocal responsibilities, that they owe each other and turns apparently democratic decisions into potential acts of domination, as theorized by both Pettit (1997) and Bohman (2006). It suggests that we should embrace a more encompassing and dialogical notion of democracy which translates Pallasmaa's (2012) notion of hapticity from the field of physical architecture to that of institutional architecture. It concludes by suggesting that there are already institutional architectures in the EU which lend themselves to a haptic declension, for example the European Semester.
\end{abstract}

Keywords: European Union, intergovernmentalism, democracy, domination, hapticity

WE ARE AT THE CUSP OF EPOCHAL CHANGES NOT JUST IN THE WAY IN which democracy is or can be practised, but also in the way in which we should conceptualize democracy itself. Just as political thinkers

* Simona Piattoni is Professor of Political Science at the University of Trento. Contact email: simona.piattoni@unitn.it.

(C) The Author 2017. Published by Government and Opposition Limited and Cambridge University Press 
refashioned the notion of democratic government during the seventeenth and eighteenth centuries - marking the passage from republican notions of democracy premised on direct participation to liberal notions of democracy based on representation - so we are today called to reconceptualize democracy for the changed 'circumstances of political organization' (Weale 1999: 10); that is, for the highly interconnected context in which we live. This task is all the more urgent for European citizens who are not only feeling the impact of globalization but also have decided since the $1950 \mathrm{~s}$ to further intensify their cooperation and to pool their sovereignty in many areas of public policy to an unprecedented extent by creating the European Community (later Union).

The promises of the European Union (EU) - to bring lasting peace and prosperity to the European continent - while not completely jettisoned by recent events, appear further from sight than at any point since the end of the Second World War. The euro crisis revealed the flawed premises upon which Economic and Monetary Union (EMU) governance was constructed, and the refugee crisis brings the consequences of the wars that flare up all around us right to our doorsteps. True, war is not raging in the EU itself, but some of the egoistic and nationalistic reactions that in the past have led to internecine war can also be observed today. Egoistic pursuit of a narrowly defined national interest, impatience with EU-level decision-making procedures, unilateral suspension of collective agreements, disregard for the application of jointly decided rules and a mounting disenchantment with the European project mark our daily political lives. We just commemorated the hundredth anniversary of the onset of the First World War. We were reminded by two widely read historical accounts - Margaret MacMillan's The War that Ended Peace (2013) and Christopher Clark's The Sleepwalkers (2013) - how the First World War was not written in the stars but was the result of discrete decisions made by European leaders, none of which, with the exception of the final declaration of war, was in itself irretrievable but which incrementally built up a situation in which war became 'inevitable'.

Lest this picture appears too bleak, let us remember the steadily declining turnout at European Parliament (EP) elections (from 62 per cent in 1979 to 42.6 per cent in 2014), ${ }^{1}$ the rise of populism everywhere in Europe ${ }^{2}$ and the declining numbers of EU citizens who think that 'the European Union has been good for their 
country' recorded by successive runs of Eurobarometer surveys (European Parliament 2015). ${ }^{3}$ Let us remember the scathing press that leaders like Angela Merkel have received in some southern EU member states and, vice versa, the stigmatization that the 'national character' of some southern European populations has received in Germany (Matthijs and McNamara 2015). It is probably not since the immediate post-war period - when it was common to invoke the supposedly 'authoritarian personality' of the Germans (Adorno et al. 1950) or the 'anarchic character' of the French (Duverger 1954) as explanations of political behaviour - that such sweeping characterizations of the various peoples of Europe have been made! As political scientists, we are called to move beyond this type of simplistic analysis and to try to understand the deeper causes of these developments. My aim will be to show ways in which we could rethink democracy for our current times.

More specifically, I will argue that the conventional wisdom according to which EU intergovernmental forums are, particularly in times of crisis, the most effective and legitimate deliberative decisionmaking structures - is deeply flawed. The turn towards intensified intergovernmentalism has aggravated, rather than ameliorated, the effectiveness and legitimacy of EMU. I will also suggest that intergovernmentalism is captive of a hyper-rationalist political science which sees citizens as parcelled out in state units and attributes to these units singular interests that need to be maximized in order to achieve democratic legitimacy. I will contrast to this vision a haptic notion of democracy that necessarily takes into account the highly interconnected context within which citizens deliberate and state units operate, and that premises democracy upon fully tracking the interests and ideas of all affected citizens wherever they may live, particularly those in other member states.

In what follows I will first discuss the rise of intensified intergovernmentalism in the EU and the ways in which it has been theorized, and normatively justified, as an appropriate mechanism for arriving at decisions, especially in times of crisis. I will then illustrate the governance architecture of EMU, particularly as it was shaped by decisions made during the crisis. I will further discuss a notion of democracy - transnational democracy - appropriate for the highly interconnected context in which we live based on the legitimating value of non-domination. I will then introduce the notion of hapticity and argue that this architectural concept, equally 
applicable to physical and to institutional architectures, is highly suggestive of the kinds of qualities that we should expect from EU institutional architectures. I will conclude by suggesting how some of the procedures that regulate EMU could be revised in order to intensify their haptic qualities. Lest we subscribe to a vision according to which retrenchment from globalization and repatriation of economic policy as well as segmentation of product and labour markets within national borders - that is, a return to separate national economies and societies - is the sole solution to the current crisis, we must find a way to adapt our democratic institutions to the interconnected circumstances of political organization of our times.

\section{THE EURO CRISIS AND THE RISE OF INTENSIFIED} INTERGOVERNMENTALISM

The long debate on the nature of the $\mathrm{EU}$ and its democratic legitimacy (Piattoni 2015a, 2015b) has recently taken a new turn. It is now widely held that the euro crisis triggered an intensification of the 'intergovernmental method' that had been enshrined in the Maastricht Treaty and further formalized and institutionalized in the Lisbon Treaty. In itself, this is not surprising: all crises 'verticalize' power. Under the pressure of events, when decisions must be made swiftly and authoritatively, power shifts towards the executive apex of the political system - in the case of the Union, towards the European Council and the Council. However, while intergovernmental negotiations have been the mechanism for arriving at major decisions on the direction and pace of integration, the Community method has been the method for making ordinary decisions (Dehousse 2011).

In EU studies, intergovernmentalism traditionally indicates the decision-making mode typical of important negotiations among heads of state and government taking place during the informal occasional summits - later institutionalized as European Council meetings - in which 'grand bargains' on European integration were struck (Moravcsik 1998) or the equally exceptional meetings of national representatives in the intergovernmental conferences (IGCs) which detailed and concluded treaty revisions. This term is now used to indicate a much larger set of negotiations which take place in very frequent meetings not only of the national ministers in various Council formations, but also during the increasingly frequent 
(though often still informal) meetings of the heads of state and governments in the European Council aimed at setting the political agenda for the Union. Helen Wallace, who listed five distinctive decision-making modes for the EU, preferred to call this phenomenon 'intensive transgovernmentalism' to connote 'the greater intensity and denser structuring ... where EU member governments have been prepared cumulatively to commit themselves to rather extensive engagement and disciplines, but have judged the full EU institutional framework to be inappropriate or unacceptable, or not yet ripe for adoption' (Wallace 2010: 101).

This method was enshrined in the Treaty on European Union in Maastricht when the momentous decision to equip the European community with legal personality in the realm of the Common Market was made and a simultaneous decision was also made to leave common foreign and security policy (CSFP) and justice and home affairs (JHA) under the control of the member states. It was deemed that these policy areas were so close to the core functions of sovereign states that the intergovernmental method ought to be preferred. As Sergio Fabbrini (2013) puts it, in Maastricht two constitutions a supranational constitution and an intergovernmental constitution were simultaneously entrenched. The differentiation that was introduced in Maastricht across policy pillars was also imported into EMU which, it was decided, was to be governed by a mixed regime of supranational monetary and exchange rate policies on the one hand, and national fiscal and budgetary policies on the other. There is broad consensus that the 'Maastricht compromise' was entered into under the pressure of events, as a way of anchoring a reunited Germany to Europe also for the future (Delors 2013; Risse et al. 1999), and that this decision sowed the seeds for future problems.

Conventional wisdom now has it that only a few economists had anticipated the problems that would arise once the contradictions of a common monetary and exchange policy superimposed onto very different real economies and fiscal regimes exploded (e.g. Wyplosz 1997, but see also Martin and Ross 2004; Notermans 2000; Verdun 1996 for early political science contributions to that effect). It was doubted that the mixed regime of EMU would be able to effectively contain the external shocks that would sooner or later hit the euro area, and it was rather concluded that no measure of cooperation in the management of macroeconomic quantities could avert the deflationary bias implicit in the attempt to respect the 
convergence parameters (Feldstein 1997). The decision to separate monetary policy neatly from fiscal and budgetary policy and to entrust the former to an arch-independent central bank, the European Central Bank (ECB), was probably due to a mix of factors, among which were the distrust that national governments harboured vis-à-vis one another in respect of the mutual commitment to stick to the parameters set in Maastricht and then reiterated through the Stability and Growth Pact (SGP) and to the adoption of a particular economic theory (ordo-liberalism or rules-based economic governance; Schmidt 2015). In the end, however, even the economists concluded that EMU was, in the absence of capital controls, the best bet between 'allow[ing] exchange rates to float freely or accept[ing] the complete domination of Germany's Bundesbank over Europe's monetary policy' (Wyplosz 1997: 18).

This mixed regime has engendered numerous ambiguities which have contributed to delegitimizing it, yet it is imperative for the sustainability of the Union that the institutions of EMU be perceived as legitimate by the citizens of the euro area (Begg et al. 2015) - the alternative being the demise of the euro. Whatever the reason for moving ahead with an EMU governed by a mixed regime, whether or not we consider it legitimate depends on a number of normative and empirical assumptions which underpin our notion of democracy.

Every conception of democracy must possess at least three components to be complete. First, it must offer an articulation of the values that relate collective decisions and actions to the interests and views of the individuals who compose a collectivity. ... Second, every democratic conception must recommend institutions - for example, political liberties, competitive elections, universal suffrage, civic associations, referenda, town meetings, and peak bargaining arrangements - that advance its underlying values. Third, values and institutional prescriptions are typically connected deductively by presuming empirical facts - often quite stylized - about the political psychology and capabilities of individuals and about sociopolitical dynamics. (Fung 2007: 444-5)

In order to capture the notion of democracy underpinned by intergovernmentalism, we must ask what are its normative and political assumptions, how and why EMU was constructed this way, and what is the backbone of its governance structure. The empirical assumptions of intergovernmentalism are that citizens' preferences are aggregated at the national level and that national governmental representatives strike bargains among themselves on the basis of these preferences. National negotiators are supposedly legitimated by 
the chain of representation that runs from the national constituencies through the national parliaments to the national executives to enter agreements and make commitments with one another (Curtin 2007, but see Agné 2015). ${ }^{4}$

From a liberal intergovernmental point of view, the way in which EMU was decided is not surprising at all. Moravcsik (1993, 1998) contends that European integration is the result of national representatives striking constitutional 'grand bargains' and deciding upon common policies only to the extent that these policies serve to promote the national interest. Minimum common denominator decisions are normally expected to ensue from these deals. In this view, delegation of tasks and powers to supranational institutions is strictly functional to ensuring that the agreements will be respected and no one will free-ride on the commitment of the others. Guarded trust, if not outright distrust, is the psychological predisposition of rational negotiators that try to maximize their advantage and prevent free-riding on the agreements (Piattoni 2016). This explains why member state representatives decided to entrust monetary policy to an arch-independent ECB (modelled after the German Bundesbank) which would not be influenced by national politics.

The mixed regime therefore seemed to represent a suitable compromise that would allow the Union to move forward in monetary matters while at the same time retaining fiscal, budgetary and social policies within the purview of national governments. It was deemed (erroneously) that monetary policy, being an exceedingly technical policy area, would not elicit the interest and passions of EU citizens and could therefore be hived off to a technocratic institution. As it turned out, this neat separation of monetary versus fiscal and budgetary policy proved untenable and the decisions of the European Council and even of the ECB have in fact become highly 'political'.

But the Maastricht compromise and the subsequent euro crisis may have also been the consequence of a more systematic, yet somewhat paradoxical, mechanism which has been in place since the beginning. According to Jones et al. (2015), integration proceeds pretty much as neofunctionalists would have predicted, through successive crises which, however, originate from the insufficient capacity of the intergovernmental negotiators to give convincing and durable responses to the challenges of the day. The partial and incomplete nature of these responses - which are taken according 
to mainstream intergovernmental theory - later force national representatives to move towards greater integration in order to correct the negative consequences of their original decisions. Hesitation and lack of clairvoyance are, according to this view, intrinsic to EU integration and not just occasional mishaps. This mechanism, which combines two theories often seen as antithetical to one another, has been dubbed 'failing forward' (Jones et al. 2015). So, in a perversely ironical way, the limited rationality and the even more limited trust which, according to liberal intergovernmentalism, characterizes these negotiations push national representatives down the road of an ever deeper integration pretty much as neofunctionalism would have predicted.

A more recent strand of intergovernmentalism claims that, since Maastricht, intergovernmental deals deepen integration by creating new (de novo) supranational institutions, to which national representatives entrust delivery and enforcement of agreements rather than transferring additional competences to existing supranational institutions. According to the proponents of this new brand of intergovernmentalism, 'European integration without supranationalism' is premised upon 'an increasingly deliberative and consensual approach to EU-decision making' (Bickerton et al. 2015: 1). In particular, the deliberative character of this 'new intergovernmentalism' would suggest that a new set of values and empirical assumptions underpin the kind of democracy embodied in the institutions which it tends to create (so this is a second reason why this brand of intergovernmentalism is new; see also Puetter 2012). In this case, what supposedly legitimizes national representatives is not so much their being at the end of a chain of delegation (that too), but their interacting with one another with the aim of reaching deliberative consensus, a method which Chancellor Merkel notoriously dubbed 'the Union method'.

While still sharing with liberal intergovernmentalism the understanding of how national preferences are formed, "new intergovernmentalism' allows for their modification through deliberation in intergovernmental forums in which the force of good arguments, and not the force of numbers, supposedly carries the day. This being the case, it would then become democratically legitimate to apply this method to decisions in policy areas that belong both to high politics and to low politics and to entrust their enforcement to de novo institutions, even technocratic ones. The shift to this method 
occurred in Maastricht in conjunction with the acceleration of globalization, the rise of neoliberalism and, more decisively, the sudden depletion of that 'permissive consensus' that had sustained the integration project until that moment (Hooghe and Marks 2009; Schimmelfennig 2014). The limits of the intergovernmental responses given to cope with globalization and increased interdependence, however, emerged just as trust in the wisdom of the deals struck until that moment by national representatives also evaporated (something which 'failing forward' also notes).

The reaction has been retrenchment towards enfeebled, although still existing and familiar, national political economic traditions. The defence of national socioeconomic compromises took precedence over attempting bold new strides towards a common macroeconomic governance architecture. Aware of the reluctance to abandon or overhaul entrenched systems of economic and social regulation, intergovernmental negotiators preferred to invoke coordination and let the market do the disciplining: ${ }^{6}$

Thus, with the 2000 Lisbon Strategy ... member states preferred peer pressure and the exchange of best practices under the Open Method of Coordination to the codification of reform commitments under the Community method. Liberalisation in general is consistent with institutional diversity at the national level. ... The institutional settings of the new intergovernmentalism are thus clearly intended as ways of achieving collective goals but in a context of entrenched national specificities that cannot be eliminated by legally binding supranational rules. (Bickerton et al. 2015: 25)

If that was the goal, it was miserably missed: EMU in fact pushes all euro-area member states towards the same export-led, internaldeflation growth model, which does not fit all of them equally well.

Whether we subscribe to liberal intergovernmentalism, new intergovernmentalism or failing forward, it would appear that the institutional architecture of EMU that was decided in Maastricht was incomplete and faulty, and yet it was, or was considered to be, the only legitimate arrangement - at least insofar as we subscribe to an intergovernmental set of values and stylized facts. Retaining fiscal, budgetary and social policy among national competences was considered not only the feasible, but also the right thing to do.

Is this mixed regime truly legitimate or is it rather undermining the democratic legitimacy of both EMU and member states' decisions? What is at fault here: the normative values, the institutional 
architecture or the stylized facts about the political psychology and capabilities of individuals and about sociopolitical dynamics upon which the conventional idea of democracy as 'representation with accountability' is premised? In other words, is this an appropriate notion of democracy for a highly interdependent setting like the EU? Can intergovernmentalism - whether liberal, new or failing forward from crisis to crisis - really legitimate further integration in other sensitive policy areas such as fiscal, budgetary and even social policy? Can national leaders act as sole intermediaries between national constituencies and EU decision-making mechanisms? Alternatively, can they still credibly ask for the vote of their national constituencies on the promise that they will win back full sovereignty for their national people?

My contention is that the solution to the democratic paradox which the EU has steered itself into could come in part from a change in discourse from national elites, which should acknowledge that new democratic values are appropriate for an interconnected setting like the EU, and in part from the articulation of a new notion of democracy as based upon 'shared and responsible sovereignty'. In what follows I will look at the democratic sustainability of the Union and argue that intergovernmentalism - whether liberal, new or failing forward - cannot normatively sustain European integration in the future. We need to think innovatively about a new kind of institutional architecture which would allow the Union and its member states to be both responsive and responsible vis-à-vis one another as well as collectively towards the rest of the world. I dub this new kind of institutional architecture 'haptic' - a term borrowed from architectural theory.

\section{THE INSTITUTIONAL ARCHITECTURE OF EMU AFTER THE CRISIS}

The root causes of what is now called the euro crisis - because it has shaken confidence in the sustainability of the common currency are still debated. Being overdetermined, their identification is largely a question of economic convictions and a way to implicitly predetermine a preferred solution. Depending on where the ultimate origin of the crisis is placed, different recommendations for reform follow, each with distinctive implications on how to legitimize the suggested measures (Jones 2015). 
Some scholars point directly to the long-term impossibility of the EMU servicing equally well economies characterized by profoundly different productive structures and industrial relations systems - by different varieties of capitalism, as it were (Bonatti and Fracasso 2013; Hall 2013). Others claim that a crisis was sooner or later due to happen, given the deflationary spin implicit in EMU governance arrangements and in the economic theory that inspired it (Bibow 2012; Feldstein 1997; Lane 2012). Still others say that the mistake was the creation of a common market for financial products in the absence of common banking regulations and sufficient resources to provide the system with liquidity in case of a 'sudden stop' and consequent banking problems (Jones 2015). The latter explanation especially, by exposing the inconsiderate decision to create a single financial market while leaving banking regulation incomplete, is an indictment of the lack of clairvoyance of national negotiators and of their direct responsibility in creating the conditions for a euro crisis (Jones et al. 2015).

Of course, the mainstream narrative, that which has had widest currency among the public and the press, is based on the profligacy of the debtor countries and the lack of solidarity of the creditor countries (Habermas 2012; Matthijs and McNamara 2015). This narrative glosses over the very different sources of problems in the various southern European countries (Ireland included) and the equally different sources of virtuousness of the northern European countries. What is often overlooked is how different the origins of the euro-area member states' problems have been, how differently they have been treated since the onset of the crisis, and how differently common solutions may be perceived by the national constituencies. The mainstream narrative, however, also tells us a story of incremental and difficult decisions made under the pressure of events by national leaders which invariably appeared to do 'too little, too late'. And yet the increasing empowerment of the European Council (equipped with a permanent presidency and secretariat and the further differentiation within it of a euro summit formation) and the parallel differentiation within the Economic and Financial Affairs Council (ECOFIN) of a euro group (also endowed with a permanent presidency and secretariat) are often justified in normative terms as the sole formations legitimated to make hard choices in difficult times. As I have argued above, these forums may in fact lack democratic legitimacy according to a new notion of democracy which takes 
full account of the heightened interdependence in which we live, hence the move 'Towards a Genuine Economic and Monetary Union' - as the first draft of the EU institutions' plan to solve the crisis was entitled - runs the risk of appearing even more ominous (Van Rompuy et al. 2012), the alternative being the dismantling of the euro and the repatriation of monetary and exchange rate policy to the member states. ${ }^{7}$

So, while it is argued that only democratically elected heads of state and governments can legitimately make difficult decisions, particularly in times of crisis, there are many arguments to the contrary. There is, for example, a legal literature that underscores the dubious legality of the agreements and international treaties signed under the pressure of the crisis (De Witte 2012; F. Fabbrini 2015). Other scholars lament the increasing marginalization of the EP in the governance architecture implemented after the crisis (Crum 2013; Fasone 2012). Others still suggest that the politicization of the office of Commission president - particularly but not only by linking its election to the European Parliament electoral results - would come close to creating a tighter relationship between representative assembly and 'government of the Union' (particularly if the president of the Commission were to also serve as president of the European Council, the 'double-hatted president'; see Pernice 2012: 23), thus drawing the EU closer to a parliamentary democracy. Yet there is an equally strong argument that this would cause the Commission presidency and the entire Commission to lose their impartiality and credibility that are still so crucial for the implementation of a strengthened SGP (S. Fabbrini 2015).

In order to move beyond the above alternative, we need a new notion of democratic legitimacy which is based less on the power to decide (the exertion of will) and more on the power to shape policy (the expression of judgement) (Urbinati 2006). Judgement implies both an active doing - activating and proposing - and a passive doing - receiving and surveilling. It implies the power to initiate deliberation as well as the power to repeal unjust laws. It must be premised on a haptic vision of democracy that monitors the externalities and uneven costs imposed onto all the citizens belonging to the Union even when decisions are democratically made at member state level. Legitimacy is not secured by identifying chains of delegation and accountability that connect the national sovereign peoples to the national decision-makers, but by making sure that 
decisions fully track the interests and ideas of all affected people and that these always have the possibility to scrutinize and, if necessary, revise the decisions made.

Neither intergovernmentalism per se nor a greater involvement of the European Parliament nor again the increased politicization of the European Commission will be sufficient to restore the legitimacy of EMU and democratic support for the EU. As argued by Bellamy and Weale (2015), the representatives of the several peoples of Europe must have the possibility to provide their input not only on the rules which guide EMU and the ECB but also on fiscal, budgetary and social policy. The Stability and Growth Pact - agreed on in 1997, amended in 2005, and further strengthened by the Six-Pack in 2011 and by the Two-Pack and by the Fiscal Compact in 2013 through intergovernmental agreements - reflects a particular economic orientation - ordo-liberalism (Bonatti and Fracasso 2013) or 'government by rules' (Van Lear 2000) - which may suit some, but certainly not all, member states' economies. Rules are only apparently neutral, but may in fact be instruments of domination. The diversity in varieties of capitalism reflects also enduring diversity in social constitutions. Balanced budget rules have been underwritten by some 25 member states (including several member states which do not belong to the euro area), but it is unclear to what extent this important decision, although formally ratified by national parliaments, was taken after an informed public debate and was therefore really legitimated by popular control.

The solution which salutes the greater involvement of the European Parliament also glosses over these important differences and rather points in the direction of the creation of a sort of European federal state. ${ }^{8}$ In the European Parliament, despite the increasing institutionalization of partisan-political alignments, national cleavages are still prevalent: a significant empowerment of the EP may end up imposing some national preferences over others (S. Fabbrini 2015). Moreover, the Two-Pack has institutionalized automatic correctives for those member states which exceed the SGP parameters, imposing sanctions that cannot be easily lifted (unless by reversed qualified majority voting in the Council). In fact, the interpretation of these rules is the object of incessant bargaining among national representatives, with the result that they are often flouted. If there is something more damning for legitimacy than blindly applying rigid rules, it is professing trust in rigid rules while 
failing to abide by them. Greater involvement of the EP, therefore, would not go very far in legitimizing EMU. National parliaments are only superficially involved in these decisions but are de facto cajoled into accepting rules which they cannot revise through informed discussion. The Economic Dialogue, which has been institutionalized by the Six-Pack and which allows the EP to hear the presidents of the Commission, of the Council and of the ECB on economic matters, is a pale imitation of a proper parliamentary accountability procedure and still subscribes to a notion of democracy as 'representation with accountability' which is inappropriate for interconnected settings like the EU.

Also, the proposal to politicize further the office of the president of the Commission is not convincing, at least not on its own. Linking the name of the candidates for the position of Commission president to the political parties sitting in the European Parliament does not amount to a real politicization of 'the government of the Union' for well-known reasons: (1) the parties which sit in the EP are themselves wide aggregations of national parties and therefore internally not very cohesive; (2) since no party ever obtains absolute majority in the EP, none can impose a political line on the candidate that it proposes for office, so that any successful candidate needs also to receive votes from other political formations, thus diluting his/her partisan identification; finally and most importantly, (3) the Commission president has very little room for manoeuvre in choosing his/her own cabinet, whose composition once more reflects the different orientation of the current member states' governments and is not accountable to the European Parliament in the same way that national executives are accountable to their parliaments. And apart from that, rule-based economic governance means that the EP could not decide much on the issues that matter for socioeconomic performance anyway. The reform of the Commission, which would reduce the number of commissioners, thus not granting each member state 'its own' commissioner, has been postponed and finally suspended. This reform might in theory prompt the formation of partisan alliances, but it might as well lead to the formation of lineups of commissioners according to some 'magic formula' which takes into account all possible national cleavages.

Even assuming that the Commission could be considered as 'the' government of the Union, its lack of internal political coherence and the fact that it still cannot be taken down by a vote of parliament 
make it substantively unresponsive to EU citizens. The plan to push the Union towards a federal state, therefore, needs to be looked at with extreme caution (see the provisos contained in Maduro 2012). The joint effect of a dramatic politicization of the Commission and of the creation of federal structures as those foreshadowed by the Four Presidents' and Five Presidents' Reports would end up giving substance to fears of domination from the largest and richest member states. Much more promising appears to be the greater involvement of national parliaments (or national parliamentary committees) in the macroeconomic policy discussions and in the eventual constitutionalization of macroeconomic rules (Manzella 2012). What are the normative foundations of such an involvement?

\section{DEMOCRACY AS NON-DOMINATION}

The most significant challenge which EU member states face today is their heightened interdependence. In and of itself this is nothing new. The EU was founded on the acknowledgement of existing and further intensification of functional interdependencies among its member states as a way of preventing any future war among them and of reaping larger economic benefits from the creation of a common market - a dual goal which is conventionally captured by the phrase 'peace and prosperity'. A larger, stronger Union would be able to negotiate on a par with other regional economic powers like the US and China (Jacoby and Meunier 2010). By pooling their sovereignty, therefore by forgoing part of their autonomy, the citizens and the states of the EU would attain higher levels of freedom and choice.

Democracy captures the right of all human beings to govern themselves freely. The current 'circumstances of political organization' (Weale 1999: 10) are such that citizens of any given state are no longer sovereign, since they are no longer in control of their destinies. Perhaps they never were, but classic and modern political thought has identified sovereignty with autonomy, literally 'self-rule'. The lives of contemporary European national citizens are affected by decisions taken elsewhere, first and foremost in the other member states. Likewise, their decisions affect the lives of the citizens of other member states. The challenge for the EU, particularly in times of crisis, is to identify the principles that can restore a new understanding of democracy in a highly interconnected context. 
Among the foundational values upon which the legitimacy of the EU could be grounded - and which could perhaps better accommodate the interdependence of European member states - non-domination belongs to the republican tradition.

Domination has resurfaced as a concern for our contemporary democracies because 'the extra-territorial effects and burden which one state inadvertently imposes onto neighbouring states in a globalized and interdependent world cannot be justified by taking recourse to domestic democratic processes' (Kohler-Koch and Rittberger 2007: 26). This is a problem both for national democracies and for EU democracy, and demands the articulation of a new notion of democracy that fully considers increasing interdependence and declining state sovereignty. As Christian Joerges (quoted in Kohler-Koch and Rittberger 2007: 26) notes, 'nationally organized constitutional states are becoming increasingly incapable of acting democratically. They cannot include all those who will be affected by their decisions in the electoral process, and vice versa, citizens cannot influence the behaviour of those that are making decisions on their behalf., 9

Philip Pettit (1997) has reinterpreted the republican normative tradition identifying in 'freedom as non-domination' the founding value of republicanism. Domination for Pettit is voluntary interference on an arbitrary basis: 'the dominating party can interfere on an arbitrary basis with the choices of the dominated ... on the basis of an interest or an opinion that need not be shared by the person affected' (Pettit 1997: 22). On the contrary, 'an act of interference will be non-arbitrary to the extent that it is forced to track the interests and ideas of the persons suffering the interference' (Pettit 1997: 55). Arbitrary interference can take place even if the dominated party formally consents to being dominated. Domination is a state of fact, not a psychological state of mind:

What is required for non-arbitrariness in the exercise of a certain power is not actual consent to that sort of power, but the permanent possibility of effectively contesting it ... it must always be possible for the people in the society, no matter what corner they occupy, to contest the assumption that the guiding interests and ideas really are shared and, if the challenge proves sustainable, to alter the patterns of state activity. (Pettit 1997: 63, emphasis added)

Pettit claims that there can be domination without interference as well as there can be interference without domination. Domination may not entail interference: all that is necessary is an outstanding 
possibility of being interfered with on an arbitrary basis, even if it never materializes. Similarly, interference may not entail domination if it takes place according to procedures that allow the tracking of the interests and ideas of all affected persons. The best guarantee for a 'robust and resilient' non-domination are constitutional provisions that allow for the contestation of the laws on the basis of which interference may be exerted, screening and sanctioning devices against the interfering agents, and the fact that the interests and ideas of the interfered people are fully tracked, though not on a sectional, but on a common good basis (Pettit 1997: 56). I draw from this discussion the idea that the individual peoples of Europe must be given a real chance to discuss the principles according to which their economies will be governed and that delegating this role to governmental representatives would deprive them of their right to contribute to the formation of judgement (isegoria), the necessary precondition for the expression of will (isonomia) (Urbinati 2006).

Although compelling, Pettit's analysis does not fully address the impersonal sources of domination which emerge from increased interdependence. Because the circumstances of political organization are different from those that obtained in the eighteenth century, the new conception of democracy must go beyond the model of a self-legislating people that is at once the author and the subject of its laws and embrace a model in which democracy's subject is potentially the entire humanity. Domination may be exerted not only by physical persons or groups, but also by impersonal forces. James Bohman (2007) observes the increasing vulnerability of persons to domination in the interdependent and globalized world of today and consequently looks for a concept of democracy - within the republican tradition of democracy as non-domination - which can be applied to interconnected settings in which domination is mostly impersonal. He explicitly acknowledges that individuals can be subjected to the domination also of incompletely defined forms of international political authority that are no longer contained within any political community' (Bohman 2007: 3).

Bohman then provides us with a working definition of democracy that can be applied to an interconnected setting like the EU:

democracy is that set of institutions by which individuals are empowered as free and equal citizens to form and change the terms of their common life together, including democracy itself. In this sense, democracy is reflexive and consists of procedures by which its rules and practices are made subject to 
the deliberation of citizens themselves. Democracy is thus an ideal of self-determination, in that the terms and boundaries of democracy are made by citizens themselves and not by others. (Bohman 2007: 2)

In this new conception of democracy, "popular control over decision making' takes on a specific meaning: 'it is the interaction between communicative freedom as it is manifested in the public sphere and the normative powers by which people create and control their rights, obligations, and deontic statuses' (Bohman 2007: 5). This is what Urbinati (2006) calls the formation of judgement.

While Pettit explicitly rules out domination by impersonal forces or distant agents, Bohman's theorization allows for the inclusion of the rightful control of the dominating impact of impersonal forces like 'the market' or of hegemonic ideas such as 'monetary stability' or 'balanced budgets' that may have the very real effect of restricting the range of choices of some people without their being able to articulate alternative interests and ideas. These commitments and injunctions may be laudable in principle, but must be negotiable, particularly as the circumstances that suggested them in the first place may change. They should be decided only after fully tracking the interests and ideas of those whose freedom is interfered with and should always be subjectable to discussion and repeal. This theorization also allows for the full consideration of the rights of those who never directly interact with the dominating agents, and yet whose range of choices is negatively affected by decisions taken in ways that do not track their interests and ideas (such as the citizens of non-member states which are affected by EU decisions) (see Piattoni 2015a: 11-13). ${ }^{10}$

\section{HAPTIC (INSTITUTIONAL) ARCHITECTURES}

The complexities of interdependence make governing particularly difficult. EU member states today are neither totally sovereign nor fully bound to one another. To a large extent the government of the Union still relies on a constantly renewed pledge to seek common solutions to common problems and to transform the costs of interdependence into greater benefits, yet the Union has yet to find that institutional architecture that allows it to do this legitimately. In hard times, crafting the consensus necessary to make hard choices is all the harder. The EU must make sure that its institutional architecture enables it to make consensually those decisions that will allow it to 
weather the crisis and relaunch growth and prosperity while safeguarding peace and democracy. Consensus among national chief executives will not be enough but may rather appear to entrench arbitrary interference, hence domination.

The qualities that any democratic institutional architecture for the EU must display can be summarized by referring to the notion of 'hapticity', a concept elaborated by architectural theorist Juhani Pallasmaa and which strikes me as highly appropriate also for the task at hand (see Piattoni 2015a: 250-2). In architecture, hapticity indicates the capacity to experience buildings with all our senses, not just our eyes. According to Pallasmaa (2012), beginning with Greek architecture but particularly since the Renaissance, architectural experience has been overly intellectualized. This has occurred by assigning primacy to visual experience, the eyes being the embodiment of our intellect. 'Knowledge has become analogous with clear vision and light is regarded as the metaphor for truth. ... Western culture has been dominated by an ocular-centric paradigm, a visiongenerated, vision-centred interpretation of knowledge, truth and reality' (Pallasmaa 2012: 18-19).

This has led to the neglect of the body and the other senses, and this imbalance in our sensory system has come at a cost, because 'the look of the other objectifies, the Medusa glance petrifies everything that comes in contact with it' (Pallasmaa 2012: 23). By privileging one sensorial perspective, we lose the capacity to experience all other types of perception. 'The hegemonic eye seeks domination over all fields of cultural production, it seems to weaken our capacity for empathy, compassion and participation with the world' (Palasmaa 2012: 24-5). Closer to our topic, 'The gradually growing hegemony of the eye seems to be parallel with the development of Western egoconsciousness and the gradually increasing separation of the self and the world: vision separates us from the world whereas other senses unite us with it' (Pallasmaa 2012: 28).

What is here predicated of the ocular-centric experience of buildings bred by a hyper-rationalist architectural culture could be applied to the state-centric understanding of political communities of hyper-rationalist political science. Citizens, understood merely as citizens of states, are isolated from one another and attributed egoistic goals. In a state-centric vision of politics, all political communities are flattened onto the same format and can be perceived only as state communities. This same hyper-rational interpretation 
sees states interacting as monads, pursuing the primary goals of power and plenty, permanence and prosperity. What begins as an ontological and epistemological perspective - the way in which we theorize and study political communities - ends up becoming also a normative (an ethical and aesthetic) perspective: democracy is equated with self-determination of the political community called state.

Hapticity applied to politics, then, invites us to open up to other political communities, to perceive them other than as state communities. Pallasmaa describes in inspiring terms the haptic perception of buildings, which can be used to guide also our perception of political communities. Rather than subjecting all buildings to the sharp focus of visual perspective, he invites us to place buildings in their context, to allow the eye to also capture the peripheral vision. In the same way, rather than subjecting all political communities to the narrow focus of state perspective, we can place the citizens of political communities into a larger context and capture also the linkages that connect them to citizens placed outside those communities.

A remarkable factor in the experience of enveloping spatiality, interiority and hapticity is the deliberate suppression of sharp focused vision. This issue has hardly entered the theoretical discourse of architecture as architectural theorising continues to be interested in focused vision, conscious intentionality, and perspectival representation. The very essence of the lived experience is moulded by unconscious haptic imagery and unfocused peripheral vision ... The preconscious perceptual realm, which is experienced outside the sphere of the focused vision, seems to be more important existentially than the focused image ... Unfocused peripheral perception transforms retinal Gestalt into spatial and bodily experiences. Peripheral vision integrates us with space, while focused vision pushes us out of the space making us mere spectators. (Pallasmaa 2012: 14-15, emphasis added)

It is not just the political theorist or the philosopher who loses the capacity to conceive of any political community other than a state; the citizens are equally trained not to consider themselves other than as state citizens. All those who belong to the unfocused peripheral context are consequently obliterated, while it is precisely the unfocused vision that allows us to perceive ourselves as part of a wider community at any given time. I would claim that politics, like architecture, 'is our primary instrument in relating us with space and time, and giving these dimensions a human measure. It domesticates limitless space and endless time to be tolerated, inhabited and understood by human kind' (Pallasmaa 2012: 19). Pallasmaa thus seeks to reintroduce values 
in architecture other than the principle of perspectival perfection, just as we should try to consider other values that could sustain EU legitimacy in addition to exploring a state-centred notion of democratic legitimacy. We should reject a simplistic state-centred understanding of democracy in favour of a less focused, but more 'empathic, compassionate and participated' notion that also includes others (other EU citizens and even citizens outside the Union).

Pallasmaa contrasts the 'assertoric gaze' to the 'alethetic gaze'. In his view, the assertoric gaze is narrow, dogmatic, intolerant, rigid, fixed, inflexible, exclusionary and unmoved, whereas the alethetic gaze is multiple, pluralistic, democratic, contextual, inclusionary, horizontal and caring (Pallasmaa 2012: 40-1). The values which could help build a legitimate Union - such as non-domination, tolerance, justice, and solidarity - are equally multiple, pluralistic, contextual, inclusionary, horizontal. Sometimes also referred to as 'fragile architecture', hapticity is an architectural quality that captures the precariousness of edifices caused by the passing of time, their being located in a space shared by other buildings, and the coexistence within them of durability and transience: these characteristics could be equally applied to the European Union edifice. 'The idea of fragility suggests listening and dialogue. ... The arrogance of perfection is replaced by a humanizing vulnerability' (Pallasmaa 2000: 82, emphasis added). Hapticity then is a highly suggestive term that indicates the necessary qualities of any legitimate and sustainable institutional architecture for the highly interconnected circumstances of political organization of our times (see Piattoni 2015a: 250-2). ${ }^{11}$

\section{CONCLUSION: TOWARDS A HAPTIC INSTITUTIONAL ARCHITECTURE OF ECONOMIC AND MONETARY UNION}

Any ideal or conception of democracy is composed of both an account of important values, such as self-rule, accountability, political equality, and liberty, and a prescription about governance institutions such as elections, deliberation, or direct participation. The institutional recommendations of any conception should yield consequences that advance its central values. When a conception of democracy has institutional consequences that are consistent with its values, I say that it is in pragmatic equilibrium. If a conception of democracy proposes institutions whose consequences turn out on empirical investigation to be inconsistent with its values, then it should be revised or discarded. (Fung 2007: 444)

Which institutional architecture can best provide democratically legitimate decisions in a highly interconnected setting like the 
European Union, which understands democracy as non-domination? How can we translate the architectural notion of hapticity in political terms? Which governance institutions would stand in pragmatic equilibrium with the values that lie at the core of the EU? In concluding this article, I would like to suggest that there already are governance architectures in the European Union that can be deployed in a potentially haptic manner - architectures that were created precisely to allow the several peoples of Europe to form judgement on the terms of their life together. The European Semester is one such architecture which was originally conceived in assertoric terms, therefore 'pragmatically off-balance' with its own stated values, but which could be deployed in an alethetic manner, thus fully developing its haptic potential.

The European Semester was launched in 2011 and fully implemented for the first time in 2012 (Hallerberg et al. 2012). The distant origins of this complex procedure, which attempts to harmonize national budgets, lie in the Broad Economic Policy Guidelines (BEPGs) and the Employment Guidelines (EGs), now jointly constituting the Integrated Guidelines (IGs) which were meant to facilitate the coordination among macroeconomic policies of the member states for the attainment of the Lisbon goals. The coordination of member states' macroeconomic strategies, then, is a long-term ambition of the Union. One of the more questionable aspects of this budgetary procedure, apart from its complicated geometry, is the marginalization of the national parliaments, which get to see, discuss and approve the national budgets only six months after they are formulated through the multilateral procedure of the European Semester. The National Semester, which follows the European Semester, is ostensibly meant to allow national parliaments to process the guidelines and recommendations, but their role (and that of the European Parliament) is fairly passive and is limited to receiving instructions decided elsewhere. The hope that the National Semester may allow national parliaments to 'own' the entire budgetary procedure is therefore pretty void. Particularly for euroarea member states, the European Semester, although conceived as 'a channel of communication and moral suasion between National Parliaments and European Commission' (Hallerberg et al. 2012: 14), may in fact act as an instrument of domination.

One way to boost the alethetic qualities of the European Semester is to involve the European Parliament and the national parliaments

(C) The Author 2017. Published by Government and Opposition Limited and Cambridge University Press 
early on in the budgetary process, in fact from the beginning of the European Semester, so that they can provide the input from the national constituencies and contribute to 'fully track the interests and ideas of the persons suffering the interference' (Pettit 1997: 55). In particular, a very promising idea is to create interparliamentary committee networks that could convene regularly during the entire budgetary cycle in order to discuss macroeconomic policies as well as the fundamental principles - such as balanced budgets and rule-based macroeconomic governance - which currently inspire macroeconomic policy at EU level. National parliaments can, better than national executives, convey the judgement - needs and ideas of the national constituencies thus leaving to national executives the task of translating this judgement into actionable will. It is through 'the interaction between communicative freedom as it is manifested in the public sphere and the normative powers by which people create and control their rights, obligations, and deontic statuses' (Bohman 2007: 5) that popular control over decision-making is realized in highly interconnected democracies.

\section{ACKNOWLEDGEMENTS}

This article is based on the 2016 Government and Opposition/Leonard Schapiro Lecture given at the Political Studies Association annual conference at the University of Sussex, Brighton, 21 March.

\section{NOTES}

${ }^{1}$ See: www.europarl.europa.eu/elections2014-results/en/turnout.html.

${ }^{2}$ There is a wide literature on the rise of populism in Europe and elsewhere. For a global, historically contextualized account, see Moffitt (2016).

3 The worst record so far of this question, asked twice a year since 1975, was in the spring of 2015, when only $47 \%$ of EU citizens thought that the EU had been good for their country, $18 \%$ answered that it had been bad, $29 \%$ neither good nor bad, and $7 \%$ did not know. See European Parliament (2015).

${ }^{4}$ I have argued elsewhere (Piattoni 2013) that this view is premised on a partial notion of 'representation as delegation', which is in fact ultimately a form of mere authorization.

${ }^{5}$ Frankly, the way in which draconian measures were imposed on Greece, let alone the content of such measures, bespeak domination rather than deliberation.

${ }^{6}$ For the notion of governance architecture, see Borrás and Radaelli (2011). 
${ }^{7}$ In fact, if the euro has not collapsed it has been because of the unconventional measures taken by the ECB, which has de facto overstepped its mandate while formally keeping within its boundaries.

${ }^{8}$ See, for example, the so-called Four Presidents' Report (Van Rompuy et al. 2012) and Five Presidents' Report (Juncker et al. 2015).

9 For equally effective statements of these circumstances, see also Innerarity (2015), Maduro (2012) and Pernice (2012).

${ }^{10}$ By permission of Oxford University Press. Extract from pp. 11-13 (570w) Ch. 1: 'The European Union: Legitimating Values, Democratic Principles and Institutional Architectures' by Simona Piattoni from European Union: Democratic Principles and Institutional Architectures in Times of Crisis edited by Piattoni, Simona (2015). http:// www.oup.com.

11 By permission of Oxford University Press. Extract from pp. 239-252 (925w) Ch. 12: 'European Union Institutional Architectures: Structural Tensions, Dynamic Forces and the Advantages of Hapticity' by Simona Piattoni from European Union: Democratic Principles and Institutional Architectures in Times of Crisis edited by Piattoni, Simona (2015). www.oup.com.

\section{REFERENCES}

Adorno, T., Frenkel-Brunswik, E., Levinson, D. and Sanford, N. (1950), The Authoritarian Personality (New York: Harper \& Row).

Agné, H. (2015), 'Popular Power in the European Union: Delegated or Alienated?', in S. Piattoni (ed.), The European Union: Democratic Principles and Institutional Architectures in Times of Crisis (Oxford: Oxford University Press): 46-62.

Begg, I., Bongardt, A., Nicolaïdis, K. and Torres, F. (2015), 'EMU and Sustainable Integration', Journal of European Integration, 37(7): 803-16.

Bellamy, R. and Weale, A. (2015), 'Political Legitimacy and European Monetary Union: Contracts, Constitutionalism and the Normative Logic of Two-level Games', Journal of European Public Policy, 22(2): 257-74.

Bibow, J. (2012), 'To Make or to Break the Euro: Germany's Euro Trilemma', Levy Economic Institute of Bard College Working Paper 271, www.levyinstitute.org/pubs/wp_721.pdf.

Bickerton, C., Hodson, D. and Puetter, U. (2015), The New Intergovernmentalism: States and Supranational Actors in the Post-Maastricht Era (Oxford: Oxford University Press).

Bohman, J. (2007), Democracy Across Borders: From Demos to Demoi (Cambridge, MA: MIT Press).

Bonatti, L. and Fracasso, A. (2013), 'The German Model and the European Crisis', Journal of Common Market Studies, 51(6): 1023-39.

Borrás, S. and Radaelli, C. (2011), 'The Politics of Governance Architectures: Creation, Change and Effects of the EU Lisbon Strategy', Journal of European Public Policy, 18(4): 463-84.

Clark, C. (2013), The Sleepwalkers (London: Penguin Books).

Crum, B. (2013), 'Saving the Euro at the Cost of Democracy?', Journal of Common Market Studies, 51(4): 614-30.

(C) The Author 2017. Published by Government and Opposition Limited and Cambridge University Press 
Curtin, D. (2007), 'Holding (Quasi-) Autonomous EU Administrative Actors to Public Account', European Law Journal, 13(4): 523-41.

Dehousse, R. (2011), The Community Method: Obstinate or Obsolete? (London: Palgrave Macmillan).

Delors, J. (2013), 'Economic Governance in the European Union: Past, Present and Future', Journal of Common Market Studies, 51(2): 169-78.

De Witte, B. (2012), 'European Stability Mechanism and Treaty on Stability, Coordination and Governance: Role of the EU Institutions and Consistency with the EU Legal Order', in European Parliament, Directorate-General for Internal Policies - Policy Department C, Challenges of Multi-Tier Governance in the European Union: Effectiveness, Efficiency and Legitimacy, PE 474.438, 78-84, www.europarl.europa.eu/RegData/etudes/ etudes/join/2013/474438/IPOL-AFCO_ET(2013)474438_EN.pdf.

Duverger, M. (1954), Political Parties, their Organization and Activity in the Modern State (London and New York: Methuen/Wiley).

European Parliament (2015), Major Trends in European Public Opinion with Regard to the European Union, updated November 2015, Directorate General for Communication (Public Opinion Monitoring Unit), www.europarl.europa.eu/pdf/eurobarometre/ 2015/major_change/eb_historical_deskresearch_en.pdf.

Fabbrini, F. (2015), 'From Executive Federalism to Executive Government: Current Problems and Future Prospects in the Governance of EMU', in F. Fabbrini, E.H. Ballin and H. Somsen (eds), What Form of Government for the European Union and the Eurozone? (Oxford: Hart Publishing): 289-306.

Fabbrini, S. (2013), 'Intergovernmentalism and Its Limits: The Implications of the Euro Crisis on the European Union', Comparative Political Studies, 46(9): 1003-29.

Fabbrini, S. (2015), Which European Union? Europe After the Euro Crisis (Cambridge: Cambridge University Press).

Fasone, C. (2012), 'The Struggle of the European Parliament to Participate in the New Economic Governance', EUI Working Papers, RSCAS 2012/45.

Feldstein, M. (1997), 'The Political Economy of the European Economic and Monetary Union: Political Sources of an Economic Liability', Journal of Economic Perspectives, 11(4): 23-42.

Fung, A. (2007), 'Democratic Theory and Political Science: A Pragmatic Method of Constructive Engagement', American Political Science Review, 11(3): 443-58.

Habermas, J. (2012), 'The Crisis of the European Union in the Light of a Constitutionalization of International Law', European Journal of International Law, 23(2): $335-48$.

Hall, P. (2013), 'The Economics and Politics of the Euro Crisis', German Politics, 21 (4): $355-71$.

Hallerberg, M., Marzinotto, B. and Wolff, G. (2012), 'An Assessment of the European Semester', European Parliament, Directorate-General for Internal Policies - Policy Department A, Economic and Scientific Policy, PE 475.121, www.europarl.europa.eu/ meetdocs/2009_2014/documents/econ/dv/studybruegel_/studybruegel_en.pdf.

Hooghe, L. and Marks, G. (2009), 'A Postfunctionalist Theory of European Integration: From Permissive Consensus to Constraining Dissensus', British Journal of Political Science, 39(1): 1-23.

(C) The Author 2017. Published by Government and Opposition Limited and Cambridge University Press 
Innerarity, D. (2015), 'Transnational Self-determination: Resetting Self-Government in the Age of Interdependence', Journal of Common Market Studies, 53(5): 1061-76. Jacoby, W. and Meunier, S. (2010), 'Europe and the Management of Globalization', Journal of European Public Policy, 17(3): 299-317.

Jones, E. (2015), 'Getting the Story Right: How Should You Choose between Different Interpretations of the European Crisis (And Why You Should Care)', Journal of European Integration, 37(7): 817-32.

Jones, E., Kelemen, D. and Meunier, S. (2015), 'Failing Forward? The Euro Crisis and the Incomplete Nature of European Integration', Comparative Political Studies, published early online, December, doi: 10.1177/0010414015617966.

Juncker, J.-C. et al. (2015), Completing Europe's Economic and Monetary Union, https:/ / ec.europa.eu/priorities/publications/five-presidents-report-completing-europeseconomic-and-monetary-union_en.

Kohler-Koch, B. and Rittberger, B. (2007), Debating the Democratic Legitimacy of the European Union (Lanham, MD: Rowman \& Littlefield).

Lane, P. (2012), 'The European Sovereign Debt Crisis', Journal of Economic Perspectives, 26(3): 49-68.

MacMillan, M. (2013), The War that Ended Peace (London: Profile Books).

Maduro, M.P. (2012), 'A New Governance for the European Union and the Euro: Democracy and Justice', in European Parliament, Directorate-General for Internal Policies - Policy Department C, Challenges of Multi-Tier Governance in the European Union: Effectiveness, Efficiency and Legitimacy, PE 474.438, 27-50, www.europarl.europa.eu/ RegData/etudes/etudes/join/2013/474438/IPOL-AFCO_ET(2013)474438_EN.pdf.

Manzella, A. (2012), 'Is the EP Legitimate as a Parliamentary Body in EU Multi-Tier Governance?', in European Parliament, Directorate-General for Internal Policies Policy Department C, Challenges of Multi-Tier Governance in the European Union: Effectiveness, Efficiency and Legitimacy, PE 474.438, pp. 138-51, www.europarl.europa.eu/ RegData/etudes/etudes/join/2013/474438/IPOL-AFCO_ET(2013)474438_EN.pdf.

Martin, A. and Ross, G. (2004), Euros and Europeans: Monetary Integration and the European Model of Society (New York: Cambridge University Press).

Matthijs, M. and McNamara, K. (2015), “The Euro Crisis” Theory Effect: Northern Saints, Southern Sinners, and the Demise of the Eurobond', Journal of European Integration, 37(2): 229-45.

Moffitt, B. (2016), The Global Rise of Populism (Stanford: Stanford University Press).

Moravcsik, A. (1993), 'Preferences and Power in the European Community: A Liberal Intergovernmentalist Approach', Journal of Common Market Studies, 31(4): 473-524.

Moravcsik, A. (1998), The Choice for Europe: Social Purpose and State Power from Messina to Maastricht (Ithaca, NY: Cornell University Press).

Notermans, T. (2000) (ed.), Social Democrats and Monetary Union (Providence, RI: Berghahn Books).

Pallasmaa, J. (2000), 'Hapticity and Time: Notes on Fragile Architecture', Architectural Review (May): 78-84.

Pallasmaa, J. (2012), The Eyes of the Skin: Architecture and the Senses (Chichester: Wiley).

Pernice, I. (2012), 'What Future(s) of Democratic Governance in Europe: Learning from the Crisis', in European Parliament, Directorate-General for Internal 
Policies - Policy Department C, Challenges of Multi-Tier Governance in the European Union: Effectiveness, Efficiency and Legitimacy, PE 474.438, pp. 4-25, www.europarl. europa.eu/RegData/etudes/etudes/join/2013/474438/IPOL-AFCO_ET(2013) 474438_EN.pdf.

Pettit, P. (1997), Republicanism: A Theory of Freedom and Government (Oxford: Oxford University Press).

Piattoni, S. (2013), 'Representation as Delegation: A Basis for European Democracy?', Journal of European Public Policy, 20(2): 224-42.

Piattoni, S. (2015a) (ed.), The European Union: Democratic Principles and Institutional Architectures in Times of Crisis (Oxford: Oxford University Press).

Piattoni, S. (2015b), 'Is the EU a Representative Democracy? The Normative Debate and the Impact of the Euro-crisis', in F. Fabbrini, E.H. Ballin and H. Somsen (eds), What Form of Government for the European Union and the Eurozone? (Oxford: Hart Publisher): 133-50.

Piattoni, S. (2016), 'The European Crisis: Testing the Trust Foundations of an Economic and Monetary Union', in B. Dallago, G. Guri and J. McGowan (eds), A Global Perspective on the European Crisis (London: Routledge): 79-95.

Puetter, U. (2012), 'Europe's Deliberative Intergovernmentalism: The Role of the Council and European Council in EU Economic Governance', Journal of European Public Policy, 19(2): 161-78.

Risse, T., Engelmann-Martin, D., Knope, H.-J. and Roscher, K. (1999), 'To Euro or Not to Euro? The EMU and Identity Politics in the EU', Journal of European International Relations, 5(2): 147-87.

Schimmelfennig, F. (2014), 'European Integration and the Euro Crisis: The Limits of Postfunctionalism', Journal of European Integration, 36(3): 321-37.

Schmidt, V. (2015), The Eurozone's Crisis of Democratic Legitimacy: Can the EU Rebuild Public Trust and Support for European Economic Integration?, European Commission, Directorate-General for Economic and Financial Affairs, Discussion Paper 015, http://ec.europa.eu/economy_finance/publications/eedp/dp015_en.htm.

Urbinati, N. (2006), Representative Democracy: Principles and Genealogy (Chicago: University of Chicago Press).

Van Lear, W. (2000), 'A Review of the Rules versus Discretion Debate in Monetary Policy', Eastern Economic Journal, 26(1): 29-39.

Van Rompuy, H. et al. (2012), Towards a Genuine Economic and Monetary Union, Brussels, 5 December 2012, www.consilium.europa.eu/uedocs/cms_Data/docs/pressdata/ en/ec/134069.pdf.

Verdun, A. (1996), 'An "Asymmetrical" Economic and Monetary Union in the EU: Perceptions of Monetary Authorities and Social Partners', Journal of European Integration, 20(1): 59-81.

Wallace, H. (2010), 'An Institutional Analysis and Five Policy Modes', in H. Wallace, M. Pollack and A. Young (eds), Policymaking in the European Union (Oxford: Oxford University Press): 69-105.

Weale, A. (1999), Democracy (London: Macmillan).

Wyplosz, C. (1997), 'Why and How It Might Happen', Journal of Economic Perspectives, 11(4): 3-21.

(C) The Author 2017. Published by Government and Opposition Limited and Cambridge University Press 